\title{
Embryonic development and larval growth of Brycon nattereri Günther, 1864 (Characidae) and its implications for captive rearing
}

\author{
Alexandre N. Maria ${ }^{1}$, Alexandre Ninhaus-Silveira ${ }^{2}$, Laura H. Orfão ${ }^{3}$ and Ana T.M. Viveiros ${ }^{4}$ \\ Embrapa Tabuleiros Costeiros, Aracaju, SE, Brazil; Departamento de Biologia e Zootecnia, Universidade Estadual Paulista \\ 'Júlio de Mesquita Filho', Ilha Solteira, SP, Brazil; Universidade José do Rosário Vellano, Campus Universitário, Alfenas, MG, \\ Brazil; Departmento de Zootecnica, Universidade Federal de Lavras, Lavras, MG, Brazil
}

Date submitted: 27.01.2017. Date revised: 24.08.2017. Date accepted: 20.09.2017

\section{Summary}

\begin{abstract}
The aim of this study was to describe, for the first time, the embryogenesis and larval growth of the Paraitinga Brycon nattereri Günther, 1864 reared in captivity. After artificial fertilization, eggs were incubated at constant temperature $\left(\sim 19^{\circ} \mathrm{C}\right)$ and collected every 15 min during the first $3 \mathrm{~h}$ and then every $3 \mathrm{~h}$ until hatching. Five larvae were collected daily over 15 days for evaluation of the length, yolk sac volume and specific growth rate. The following stages of embryonic development were identified: zygote, cleavage, gastrula, segmentation and larval. The hatching occurred after 50-54 h, with larvae poorly developed and fully depigmented, devoid of mouth and swimming capacity, presenting $6.32 \mathrm{~mm}$ total length and $3.64 \mathrm{~mm}^{3}$ yolk sac volume. The mouth opening was observed between days $3-4$ after hatching. The yolk sac absorption was slow during the first 3 days, increasing sharply after this period, being completed on the day 11. During this period there was a decrease in the larval growth rate. After yolk sac absorption, an increase in the growth rate was observed that coincided with the start of exogenous feeding. Cannibalism was not observed during the 15 days of evaluation. The initial development of $B$. nattereri was slow and poorly developed larvae in relation to other Brycon species, certainly due to the lower temperature required for egg incubation and larval rearing. Other studies are needed in order to develop techniques to improve the methods of incubating eggs and feeding larvae.
\end{abstract}

Keywords: Development, Embryo, Larvae, Neotropical, Threatened fish

\section{Introduction}

Fish species of the genus Brycon are widely spread in neotropical region from Mexico to Argentina, with 21 known species in the Cis-Andean river systems (Lima, 2017). Pirapitinga Brycon nattereri Günther, 1864 (Characiformes: Bryconidae) is an endemic species of the rivers basins of Paraná, San Francisco and Tocantins (Rosa \& Lima, 2008). This species is

\footnotetext{
${ }^{1}$ All correspondence to: Alexandre Nizio Maria. Embrapa Tabuleiros Costeiros, Av. Beira Mar 3250, Bairro Jardins, Zip Code: 49025-040, Aracaju, SE, Brazil. Tel: +55 7940091385. E-mail: alexandre.maria@embrapa.br

${ }^{2}$ Departamento de Biologia e Zootecnia, Universidade Estadual Paulista 'Júlio de Mesquita Filho', Rua Monção, 226, Zona Norte, Ilha Solteira, SP, 15385-000, Brazil.

${ }^{3}$ Universidade José do Rosário Vellano, Rod. MG 179, km 0, Campus Universitário, Alfenas, MG, 37130-000, Brazil.

${ }^{4}$ Departmento de Zootecnica, Universidade Federal de Lavras, P.O. Box 3037, Lavras, MG, 37200-000, Brazil.
}

under great threat in its natural environment due to factors such as deforestation, pollution and waters impoundment (Lima et al., 2008), and now belongs to the list of Brazilian species threatened with extinction (Ministry of the Environment ordinance no. 445/2014).

As with many Brazilian native species, little scientific information is available regarding reproductive and development characteristics. According to Lima et al. (2008), the size at first maturity in B. nattereri ranged 9.8 at $15.8 \mathrm{~cm}$ for males and 11.4 at $18.5 \mathrm{~cm}$ for females, depending on the basin in which they were caught. It has been recently reported that the gonad maturation of $B$. nattereri broodstocks kept in captivity, occurred in autumn-winter, in the colder months of the year (Viveiros et al., 2012a; Maria et al., 2015), and differs from other species of the genus Brycon, which reproduce in spring-summer (Zaniboni-Filho et al., 2006). In captivity, the collection of gametes for artificial reproduction of $B$. nattereri is possible after hormonal induction (Viveiros et al., 2012a). In this 
condition, collected sperm is of high quality (Oliveira et al., 2007; Viveiros et al., 2012a), however, stripped oocyte quality and consequently hatching rate is still very poor due to a lack of information about this species (Viveiros et al., 2012a; Maria et al., 2015).

Knowledge on reproductive and developmental characteristics provides essential information for a better understanding of $B$. nattereri and the establishment of conservation measures and captive rearing of this threatened species.

The study of embryogenesis and larval growth is important not only for taxonomic purposes, but also for captive cultivation, especially in determining when yolk sac absorption and mouth opening occurs, indicating the need for exogenous feeding (Sato et al., 2003a). These studies are a basic tool for captive production because they supply important information relating to incubation processes, larviculture and fry production. Some species of Brazilian fish threatened with extinction such as the $B$. insignis (AndradeTalmelli et al., 2002) and the B. gouldingi (Faustino et al., 2015), have been the subject of studies on embryonic and larval development.

The aim of this study was to describe, for the first time, embryogenesis and larval growth of B. nattereri. Determination of biological parameters for captive rearing are compared with other species of the same genus.

\section{Materials and methods}

\section{Artificial reproduction}

Fish used in these experiments were handled following the guidelines for animal experimentation described in Van Zutphen et al. (2001). All fish were anesthetized with benzocaine (ethyl aminobenzoate at $60 \mathrm{mg} / \mathrm{l}$ in water) before handling.

Experiments were conducted in the Fish Culture Unit of the Hydroelectric Company of Minas Gerais (CEMIG) in city of Itutinga, state of Minas Gerais, Brazil, in the months of June and July, during the reproductive period. During these months, the region is characterized by dry winters with very low rainfall volume, or no rainfall in some years, with temperatures between $14^{\circ} \mathrm{C}$ and $26^{\circ} \mathrm{C}$. The altitude in this region ranges from 910 to $1362 \mathrm{~m}$.

Embryos and larvae of $B$. nattereri were obtained after induced breeding from adult specimens held in captivity for 4 years. During the experimental period, males showed small hooklets on the anal-fin rays as a secondary sexual characteristic. Males with this characteristic and that released semen under slight pressure of the urogenital papilla and females that possessed swollen abdomen and reddish genital pore were selected for reproduction. Males $(n=10$; $329 \pm 55 \mathrm{~g})$ and females $(n=10 ; 380 \pm 79 \mathrm{~g})$ were transferred from a pond to an aquarium with water at $18 \pm 1{ }^{\circ} \mathrm{C}$ and oxygen at $7-8 \mathrm{mg} / \mathrm{l}, 48 \mathrm{~h}$ prior to hormone induction.

Each female received two intramuscular injections of carp pituitary extract (cPE; Argent Chemical Laboratory, Redmond, Washington, USA) at 0.4 and $4.0 \mathrm{mg} / \mathrm{kg}$ body weight, with a $12 \mathrm{~h}$ interval. Between $14 \mathrm{~h}$ and $18 \mathrm{~h}$ after the second dose, all females were hand stripped. Males received a single injection of $4.0 \mathrm{mg} / \mathrm{kg}$ body weight, at the same time as the second dose in females.

The water temperature of the tank was measured every hour after the second dose of hormone to calculate the degree-hours (average water temperature $x$ number of hours until spawning) and to estimate the time of spawning. Semen and oocyte collection occurred after $292 \pm 39$ degree-hours (between $14 \mathrm{~h}$ and $18 \mathrm{~h}$ ) and gametes from one male and one female were mixed, totalling 10 artificial fertilizations. Tank water was used to activate the gametes. Eggs were kept in funnel type incubators with a capacity of 200 litres, with controlled water flow and the temperature at $19 \pm 0.6^{\circ} \mathrm{C}$.

\section{Embryogenesis, larval growth and yolk absorption}

To describe the stages of embryonic development, 40 to 50 embryos were collected from incubators every $15 \mathrm{~min}$ during the first $3 \mathrm{~h}$ and then every $3 \mathrm{~h}$ until hatching. After collection, the embryos were analyzed under a stereomicroscope (Stereo Discovery v8, Carl Zeiss MicroImaging GmbH, Göttingen, Germany). The end of each developmental stage was defined as the time at which $50 \%$ of the sampled eggs were at the next stage.

To describe the stages of larval development, newly hatched larvae were transferred to plastic boxes with 30 litres of water at $18 \pm 1^{\circ} \mathrm{C}$. Five larvae were collected per day for growth follow-up from hatching (day 0) to the 15th day of life. After mouth opening, the larvae were fed with brine shrimp (Artemia salina L.). The sizes of larvae and the yolk sac were measured (length and height) using a stereomicroscope equipped with an ocular micrometer. The yolk sac volume ( $n=5$ larvae) was determined daily according with the equation proposed by Blaxter \& Hempel (1963): $\mathrm{VSV}=(\pi / 6) \mathrm{L} \times \mathrm{H}^{2}$, in which: VSV = volume of the yolk sac $\left(\mathrm{mm}^{3}\right) ; \pi=3.1415 ; \mathrm{L}=$ length of the yolk sac (mm) and $\mathrm{H}=$ height of the yolk sac $(\mathrm{mm})$.

For evaluation of the specific growth rate (SGR), five larvae were measured on days $0,3,6,10,13$ and 15 after hatching; the rate was determined by means of the following ratio: TCE $=(\ln (\mathrm{Lt})-\ln (\mathrm{L} 0) / \mathrm{t}) \times 100$, in which $L_{t}$ is the average final length $(\mathrm{mm}), \mathrm{L}_{0}$ is the 
Table 1 Embryonic development of Paraitinga Brycon nattereri

\begin{tabular}{lll}
\hline Time (h) & Stage & Observations \\
\hline $0-1.75$ & Zygote & $\begin{array}{c}\text { Zygote formation, animal } \\
\text { pole without segmentation } \\
\text { Morula formation }\end{array}$ \\
15 & Cleavage & 50\% of epiboly \\
21 & Gastrula & $90 \%$ of epiboly \\
23 & Gastrula & Blastopore closure \\
26 & Gastrula & Formation of somites, \\
29 & Segmentation & notochord, optic vesicle, \\
& & neural tube and tail stuck \\
& & Free tail, presence of optic \\
41 & Larval & vesicle, increase in the \\
& & number of somites pairs \\
& & Presence of the optical vesicle, \\
47 & Larval & embryo showing the form \\
& & of larvae to hatch, \\
& & occurrence of spasmodic \\
& & movements \\
$50-54$ & Hatching & Hatching \\
\hline
\end{tabular}

average initial length and $t$ is the growth period (days) (Puvanendran \& Brown, 1999).

\section{Results}

The period of embryonic development of $B$. nattereri from fertilization up to hatching, was $50-54 \mathrm{~h}$, at $\sim 19^{\circ} \mathrm{C}$, corresponding to 1034 degree-hours. The following embryonic development stages were observed: zygote, cleavage, gastrula, segmentation, larval and hatching (Table 1). There was heterogeneity in embryo development because different stages of development were observed at the same time.

After $1.75 \mathrm{~h}$ from fertilization, there was cytoplasmic migration with the animal pole individualization and zygote formation over the yolk. Then, the cleavage stage was characterized by a succession of mitotic divisions without increase in cytoplasmic content, and ending with the beginning of epibolic movement. The gastrula stage was marked by the beginning of the epiboly movement, when blastomeres migrated in the opposite direction to the animal pole, so that at the end of this movement the yolk was completely involuted by the blastoderm. The epiboly movement covering approximately $50 \%$ of the yolk was observed $21 \mathrm{~h}$ after fertilization; $2 \mathrm{~h}$ later, the yolk was $90 \%$ covered. The epiboly movement culminated with blastopore closure at $26 \mathrm{~h}$ from embryogenesis, when the yolk was completely surrounded by the blastoderm, forming yolk sac. The segmentation stage $(29 \mathrm{~h})$ was characterized by the formation of organs such as the optic vesicle, notochord, somites,
Table 2 Length and volume of the yolk sac (mean \pm standard deviation) of Paraitinga Brycon nattereri larvae evaluated between hatching (day 0 ) and 15 days after hatching

\begin{tabular}{lcc}
\hline $\begin{array}{l}\text { Days after } \\
\text { hatching }\end{array}$ & $\begin{array}{l}\text { Larvae length } \\
(\mathrm{mm})\end{array}$ & $\begin{array}{l}\text { Yolk sac volume } \\
\left(\mathrm{mm}^{3}\right)\end{array}$ \\
\hline 0 & $6.32 \pm 0.69$ & $3.64 \pm 0.39$ \\
3 & $8.76 \pm 0.23$ & $2.77 \pm 0.32$ \\
6 & $9.67 \pm 0.28$ & $1.49 \pm 0.28$ \\
10 & $10.23 \pm 0.82$ & $0.38 \pm 0.29$ \\
13 & $11.21 \pm 0.10$ & 0.00 \\
15 & $12.18 \pm 0.59$ & 0.00 \\
\hline
\end{tabular}

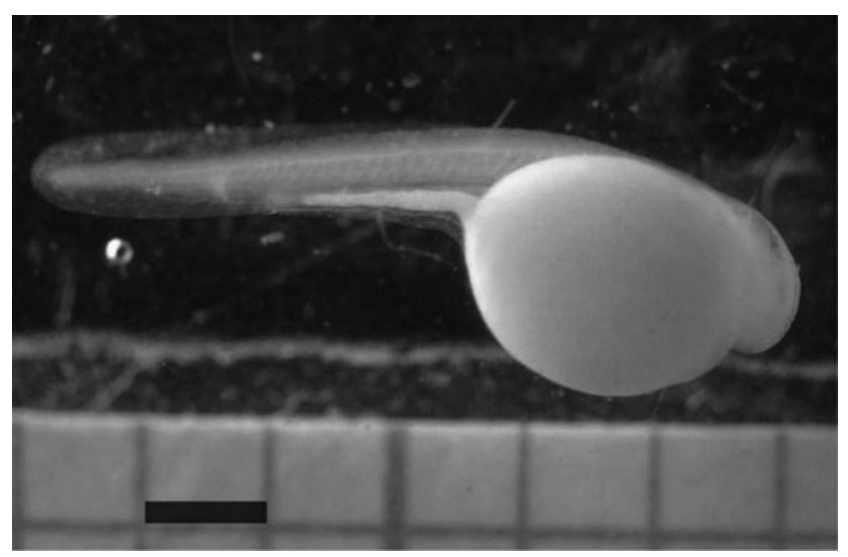

Figure 1 Recently hatched larva of Brycon nattereri. Bar = $1 \mathrm{~mm}$.

posterior intestine, prosencephalon, mesencephalon and rhombencephalon, with the consequent growth and elongation of the embryo. At this stage the embryo tail was still attached.

The embryo at the larval stage $(41 \mathrm{~h})$ was characterized by the free tail, presence of the optic vesicle, increase in the number of somites pairs, also the embryo already presented the larval form at hatching. The notochord extended from the cephalic region to the tail. Another characteristic of this stage was the occurrence of spasmodic movements by the embryos, which increased with embryonic development. At the moment of hatching, the larvae presented vigorous swimming movements, important for the disruption of the chorion. Hatching of the larvae began at $50 \mathrm{~h}$ after the fertilization, and $4 \mathrm{~h}$ later it was possible to observe that all larvae that had initiated the hatching process had disrupted the chorion.

The recently hatched larvae (day 0; yolk sac larval stage) are totally transparent, devoid of mouth, visual acuity and swimming capacity, with a $6.32 \pm 0.69 \mathrm{~mm}$ average total length (Fig. 1). The yolk sac was ellipsoid with an average volume of $3.64 \pm 0.39 \mathrm{~mm}^{3}$; the anal region was defined, but closed (Table 2). 

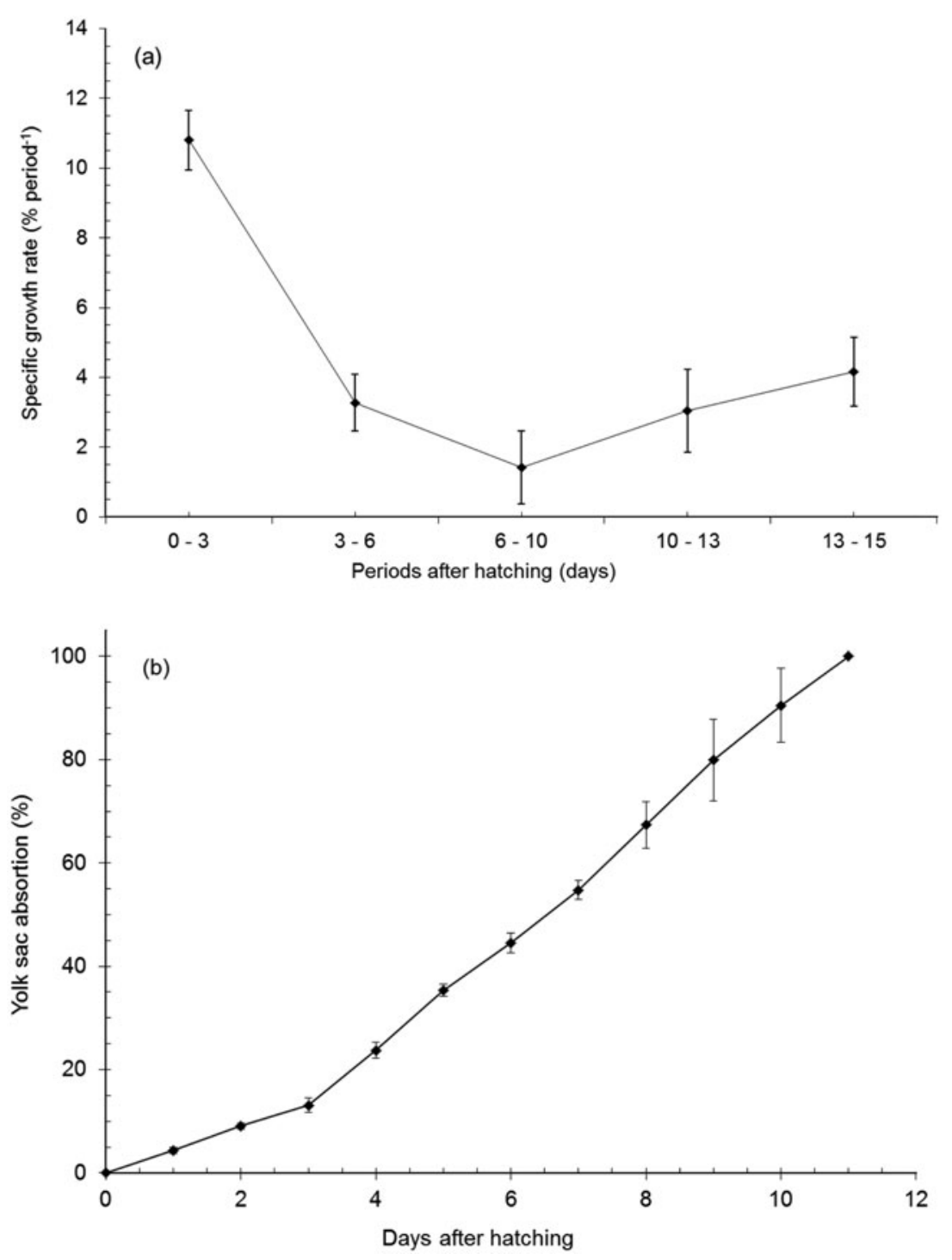

Figure 2 (a) Specific growth rate of Paraitinga Brycon nattereri larvae (mean \pm standard deviation) during five different periods of time after hatching (in days). (b) Daily absorption of the yolk sac.

On day 3 after hatching, it was possible to observe that some larvae initiated opening of the mouth, colouring of the eyes and the body, and signs of the branchial arcs. In this period they presented $8.76 \pm 0.23 \mathrm{~mm}$ in length and a large amount of yolk. On the fourth day these events could be visualized more frequently between the larvae. Up to the fourth day, all larvae were at the bottom of the culture boxes, in lateral decubitus, grouped on their extremities. The probable reasons for this behaviour would be the weight of the yolk sac and the presence of signs of the swim bladder and pectoral fins, preventing them from obtaining balance and moving in the water column. On the fifth day the branchial arcs were more developed. The larvae did not exhibit cannibalism during on the first 15 days of life.
There was a decrease in the growth rate from $10.80 \%$ between 0 and 3 days, to $1.42 \%$ between 6 and 10 days (Fig. 2a). During these first 10 days (yolk sac larval stage), the larvae absorbed the yolk, as can be observed in Fig. 2b. Absorption was slower during the first 3 days. After this period, absorption increased sharply, being concluded on the 11th day, coinciding with the start of the preflexion stage. In this period, the larvae presented intermittent swimming, consisting of short periods of activity followed by long periods of recovery. After the 11th day, the first intestinal content of the larvae was observed; the swim bladder was completely inflated and pigmented; body growth rate resumed, reaching $4.2 \%$ in the period $13-15$ days (Fig. 2a). On the 14th day, the start of notochord flexion (flexion stage) was observed. 


\section{Discussion}

The morphological events registered during embryonic and larval development of $B$. nattereri followed similar patterns previously reported for other Brycon species (Andrade-Talmelli et al. 2001; Nakatani et al., 2001; Alexandre et al., 2010; Gomes et al., 2013; Isaú et al., 2013), however the developmental stages were slower due to the low water temperature required by the species.

In this study, the closure of the blastopore occurred around $26 \mathrm{~h}$ and hatching began after $50 \mathrm{~h}$ of fertilization, when incubated at $19^{\circ} \mathrm{C}$. This temperature is usually observed in this region during the reproductive period of the species (Viveiros et al., 2012a; Maria et al., 2015), therefore it may be considered as a comfortable temperature for this species. Brycon nattereri embryogenesis can be considered as long compared with other species of the genus Brycon, such as B. cf. erythropterus (Eckmann, 1984), B. orbignyanus (Nakatani et al., 2001), B. insignis (Andrade-Talmelli et al., 2001; Isaú et al., 2013), B. siebenthalae (ClavijoAyala \& Arias-Castellanos, 2004), B. orthotaenia (Gomes et al., 2013) and B. cephalus (Alexandre et al., 2010) in which embryonic development was concluded between 11 and $30 \mathrm{~h}$ after fertilization, at 23 to $28^{\circ} \mathrm{C}$ (Table 3). Temperature is the main factor controlling the development rate of fish (Kamler, 1992). Its action in the embryonic period is connected to variation in the embryogenesis rate, and variation (asynchronicity and malformation) in the development of the embryos (Morrison et al., 2001). The development and growth of fish are interrupted below the minimum temperature limit, whereas mass mortality occurs at temperatures above the maximum limit (Kamler, 1992). In Prochilodus lineatus, the duration of embryonic development at an incubation temperature of $24^{\circ} \mathrm{C}$ was 1.6 times slower than that at $28^{\circ} \mathrm{C}$ (NinhausSilveira et al., 2006). Ectothermic animals present accelerated development in higher temperatures due to temperature-induced alterations in enzymatic activities during organogenesis (Ojanguren \& Braña, 2003). Besides temperature, the size of the oocyte is another factor that influences incubation time. According to Kamler (2002), oocyte size is responsible for prolongation of the time of specific ontogenetic phases. Brycon nattereri oocytes are larger than those of other Brycon species (Maria et al., 2015), leading to a longer incubation period.

The hatching rate observed in this study varied from 0.6 to $23.6 \%$. Despite this rate being a low value, it can be considered satisfactory as it refers to a little domesticated species that lacks scientific studies on its artificial reproduction. In other Brycon species, the hatching rates varied from 10.5 to $30 \%$ in B. orbignyanus (Belmont, 1994; Zaniboni-Filho \& Barbosa, 1996),

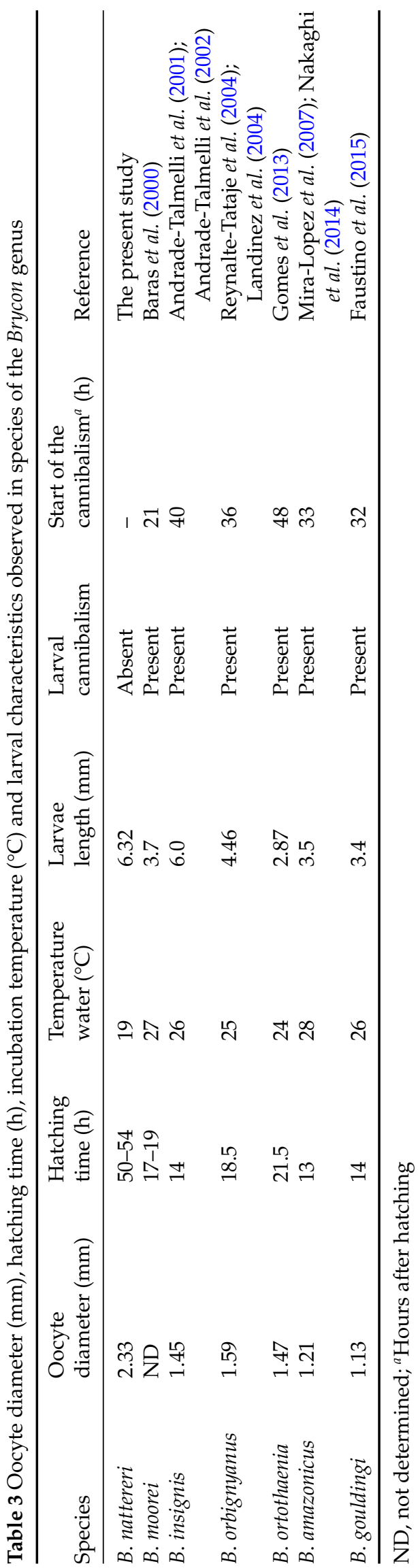


24-42\% in B. insignis (Andrade-Talmelli et al., 2002; Viveiros et al., 2012b) and 40\% in B. opalinus (Narahara et al., 2002). Funnel type incubators were used in this study, based on the shape of incubators normally used for other species of this genus. However, the low hatching rate observed may be due to the type of incubator used. Funnel type incubators (vertical format) are indicated for species that present free eggs and larvae with vertical movement in the water column (Sato et al., 2003b). These characteristics were not observed in B. nattereri, whose eggs were weakly adhesive, and the larvae, after hatching, did not move vertically in the water column. Sieve-type incubators (horizontal format) are usually used for these species (Sato et al., 2003b).

Knowledge on the development stages and larval growth of fish is important, mainly in the determination of the moment of the yolk sac absorption and mouth opening, indicators of the need for exogenous feeding. In B. nattereri, the volume of the yolk sac was 6 to 10 times larger than that of other tropical species such as B. orbignyanus $\left(0.62 \mathrm{~mm}^{3}\right.$; Reynalte-Tataje et al., 2004) and Piaractus mesopotamicus $\left(0.38 \mathrm{~mm}^{3}\right.$; Clavijo-Ayala et al., 2006), providing a longer period of endogenous feeding. This situation might be associated with the species' adaptation strategy for the environment in which it lives. Brycon nattereri spawn in the headwaters region, in clear and cold waters with lower primary productivity (Oliveira et al., 2007; Lima et al., 2008; Maria et al., 2015). Water temperature is a factor that influences the period of endogenous feeding of fish larvae because of its direct effects on their oxygen consumption, yolk exhaustion rate, feeding activity and food conversion efficiency (Kamler, 1992; Kamler, 2002; Teletchea \& Fontaine, 2010). In the present study, a lower water temperature contributed to a longer period of endogenous feeding for the B. nattereri larvae.

In this study, a high growth rate of the larvae between 0 and 3 days after hatching, reduction of the growth rate between 3 and 10 days, and resumed of growth rate between 11 and 15 days was observed. The period of growth reduction coincided with the period when the larvae have completely absorbed the yolk. According to Kamler (1992), the growth reduction of yolk sac discloses energy deficit and tissue absorption. In a study carried out with five species of freshwater fish, it was noted that the energy contained in the yolk was used mainly for tissue growth, less energy was expended in metabolism, and still less in excretion of residual materials (Jaworski and Kamler, 2002). According to these authors, energy partition was similar between different species, regardless of egg size and preference of incubation temperature. After absorption of the yolk by the B. nattereri larvae, body growth was resumed due to the beginning of the exogenous feeding, observed after the 11th day after hatching.

The total length of the $B$. nattereri larvae after hatching $(6.32 \mathrm{~mm})$ was higher than that observed for other species of the genus Brycon, such as $B$. orbignyanus (4.46 mm; Reynalte-Tataje et al., 2004). However, B. nattereri larvae presented slower initial growth in relation to this species. In this study, the $B$. nattereri larvae presented an average total length of $9.50 \mathrm{~mm}$ at 4 days after hatching, and $12.18 \mathrm{~mm}$ at 15 days. In $B$. orbignyanus, an average total length of $7.8 \mathrm{~mm}$ was observed at 4 days, and $17.60 \mathrm{~mm}$ at 15 days (Reynalte-Tataje et al., 2004). The higher length of the $B$. nattereri larvae in relation to $B$. orbignyanus at 4 days is due to the higher length of the larvae immediately after hatching, and larger oocyte size. At 15 days these values were the opposite, and the $B$. nattereri larvae were smaller. This change is probably because $B$. nattereri needs lower water temperatures, thus resulting in slower development.

Brycon nattereri larvae, after beginning of the exogenous feeding, did not exhibit cannibalism, as do most species of Brycon. Cannibalism starts in B. cephalus (Romagosa et al., 2001), B. orbignyanus (Reynalte-Tataje et al., 2004), B. moorei (Baras et al., 2000), B. siebenthalae (Atencio-García et al., 2003), B. insignis (Souza, 2004) and B. ortothaenia (Gomes et al., 2013) between 21 and $72 \mathrm{~h}$ after hatching. The incidence of cannibalism between the larvae can reach up to $60 \%$ in B. cephalus (Leonardo et al., 2008) and is responsible for high mortality during larviculture, which makes its breeding difficult, being a limiting factor for fish production (Leonardo et al., 2008). The absence of cannibalism in B. nattereri is a great advantage in the captivity production process, as it facilitates handling, reduces feeding costs and increases survival rate.

These first results of the embryonic development and larval growth of $B$. nattereri provide important information for the success of captive rearing. This species presents some characteristics that differ sharply from other species of the same genus. Brycon nattereri presents some positive aspects for captive rearing, such as better resistance to handling at low temperatures, absence of cannibalism in its initial phase, and a long period of endogenous feeding. These characteristics, among others, require the development of specific management techniques to increase their survival rate in captivity.

\section{Acknowledgements}

The authors wish to thank the Companhia Energética de Minas Gerais (CEMIG, Itutinga Unit, MG) for 
providing the broodstock and FAPEMIG for financial support (project CVZ-1609/06).

\section{References}

Alexandre, J.S., Ninhaus-Silveira, A., Veríssimo-Silveira, R., Buzollo, H., Senhorini, J.A. \& Chaguri, M.P. (2010). Structural analysis of the embryonic development in Brycon cephalus (Günther, 1869). Zygote 18, 173-83.

Andrade-Talmelli, E.F., Kavamoto, E.T., Romagosa, E. \& Fenerich-Verani, N. (2001). Embryonic and larval development of the 'piabanha', Brycon insignis, Steindachner, 1876 (Pisces, Characidae). B. Inst. Pesca 27, 21-7.

Andrade-Talmelli, E.F., Kavamoto, E.T., Narahara, M.Y. \& Fenerich-Verani, N. (2002). Reprodução induzida da piabanha, Brycon insignis (Steindachner, 1876), mantida em cativeiro. R. Bras. Zootec. 31, 803-11.

Atencio-García, V., Zaniboni-Filho, E., Pardo-Carrasco, S. \& Arias-Castellanos, A. (2003). Influência da primeira alimentação na larvicultura e alevinagem do yamú Brycon siebenthalae. Acta Scientarium 25, 61-72.

Baras, E., Ndao, M., Maxi, M.Y.J., Jeandrain, D., Thomé, J.P., Vandewalle, P. \& Mélard, C. (2000). Sibling cannibalism in dorada under experimental conditions, I. Ontogeny, dynamics, bioenergetics of cannibalism and prey size selectivity. J. Fish Biol. 57, 1001-20.

Belmont, R.A.F. (1994). Considerações sobre a propagação artificial da piracanjuba, (Brycon orbignyanus). In Seminário sobre criação de espécies do gênero Brycon, 1994, pp. 17-18. Pirassununga, SP: Anais.

Blaxter, J.H.S. \& Hempel, G. (1963). The influence of egg size on herring larvae (Cuplea harengus L). ICES J. Mar. Sci 28, 211-40

Clavijo-Ayala, J.A. \& Arias-Castellanos, J.A. (2004). Avances en el estudio de la embriología del yamú, Brycon siebenthalae (Pisces: Characidae). Dahlia 7, 37-48.

Clavijo-Ayala, J.A., Vetorelli, M.P. \& Portella, M.C. (2006). Desenvolvimento inicial e caracteres de identificação de larvas vitelinas de Pacu Piaractus mesopotamicus (Holmberg, 1887). In 4th Congresso iberoamericano virtual de acuicultura, 4, Zaragosa, CIVA 2006, pp. 819-828.

Eckmann, R. (1984). Induced reproduction in Brycon cf. erythropterus. Aquaculture 38, 379-82.

Faustino, F., Makino, L.C., Neumann, E. \& Nakaghi, L.S.O. (2015). Morphological and morphometric aspects of early life stages of piabanha Brycon gouldingi (Characidae). J. Fish Biol., 86, 1491-506.

Gomes, R.Z., Sato, Y., Rizzo, E. \& Bazzoli, N. (2013). Early development of Brycon orthotaenia (Pisces: Characidae). Zygote 21,11-20.

Isaú, Z.A., Rizzo, E., Amaral, T.B., Mourad, N.M.N. \& Viveiros, A.T.M. (2013). Structural analysis of oocytes, post-fertilization events and embryonic development of the Brazilian endangered teleost Brycon insignis (Characiformes). Zygote 21, 85-94.

Jaworski, A. \& Kamler, E. (2002). Development of a bioenergetics model for fish embryos and larvae during the yolk feeding period. J. Fish Biol. 60, 785-809.

Kamler, E. (1992). Early Life History of Fish: An Energetic Approach. London: Chapman and Hall, London, 267 pp.
Kamler, E. (2002). Ontogeny of yolk-feeding fish: an ecological perspective. Rev. Fish Biol. Fisher 12, 79-103

Landinez, M.A., Senhorini, J.Á. \& Sanabria, A.I. (2004). Desenvolvimento embrionário de piracanjuba (Brycon orbignyanus). B. Тec CEPTA, 17, 1-12.

Leonardo, A.F.G., Hoshiba, M.A., Senhorini, J.A. \& Urbinati, E.C. (2008). Canibalismo em larvas de matrinxã, Brycon cephalus, após imersão dos ovos a diferentes concentrações de triiodotironina $\left(\mathrm{T}_{3}\right)$. B. Inst. Pesca 34, 231-9.

Lima, F.C. (2017). A review of the Cis-Andean species of the genus Brycon Müller \& Troschel (Characiformes: Characidae). Zootaxa 4222, 1-189.

Lima, F.C.T., Albrecht, M.P., Pavanelli, C.S. \& Vono, V. (2008). Threatened fishes of the world: Brycon nattereri Günther, 1864 (Characidae). Environ. Biol. Fish 1, 1-2.

Maria, A.N., Orfão, L.H., Rizzo, E., Ninhaus-Silveira, A. \& Viveiros, A.T.M. (2015). Histochemical and morphological features of the intraovarian and stripped oocytes of the Brazilian endangered teleost pirapitinga Brycon nattereri (Characiformes). Zygote 23, 360-6.

Mira-Lopez, T.M., Medina-Robles, V.M., Velasco-Santamaria, Y.M. \& Cruz-Casallas, P.E. (2007). Valores morfométricos en larvas de yamú Brycon amazonicus (Pisces: Characidae) obtenidas con semen fresco y crioconservado. Actual Biol. 29, 203-13.

Morrison, C.M., Miyake, T. \& Wright, J.R. (2001). Histological study of development of the embryo and early larva of Oreochromis niloticus (Pisces, Cichlidae). J. Morphol. 247, 172-96.

Nakaghi, L.S.O., Neumann, E., Faustino, F., Mendes, J.M.R. \& Braga, F.M. (2014). Moments of induced spawning and embryonic development of Brycon amazonicus (Teleostei, Characidae). Zygote 22, 549-57.

Nakatani, K., Agostinho, A.A., Baumgartner, G., Bialetzki, A., Sanches, P.Y., Makrakis, M.C. \& Pavanelli, C.S. (2001). Ovos e larvas de peixes de água doce. Maringá: EDUEM, 378 pp.

Narahara, M.Y., Andrade-Talmelli, E.F., Kavamoto, E.T. \& Godinho, H.M. (2002). Reprodução induzida da pirapitinga-do-sul, Brycon opalinus (Curvier, 1819), mantida em condições de confinamento. R. Bras. Zootec. 31,1070-5.

Ninhaus-Silveira, A., Foresti, F. \& Azevedo, A. (2006). Structural and ultrastructural analysis of embryonic development of Prochilodus lineatus (Valenciennes, 1836) (Characiforme; Prochilodontidae). Zygote 14, 217-29.

Ojanguren, A.F. \& Braña, F. (2003). Thermal dependence of embryonic growth and development in brown trout. J. Fish Biol. 62, 580-90.

Oliveira, A.V., Viveiros, A.T.M., Maria, A.N., Freitas, R.T.F. \& Isau, Z.A. (2007). Sucesso do resfriamento e congelamento de sêmen de pirapitinga Brycon nattereri. Arq. Bras. Med. Vet. Zootec. 26, 1509-1515.

Puvanendran, V. \& Brown, J.A. (1999). Foraging, growth and survival of Atlantic cod larvae reared in different prey concentrations. Aquaculture 175, 77-92.

Reynalte-Tataje, D.A., Zaniboni-Filho, E. \& Esquivel, J.R. (2004). Embryonic and larvae development of piracanjuba, Brycon orbignyanus, Valeciennes, 1849 (Pisces, Characidae). Acta Sci. Biol. Sci. 26, 67-71. 
Romagosa, E., Narahara, M.Y. \& Fenerich-Verani, N. (2001). Stages of embryonic development of the 'matrinxã', Brycon cephalus (Pisces, Characidae). B. Inst. Pesca, 27, 2732.

Rosa, R.S. \& Lima, F.C.T. (2008). Os peixes brasileiros ameaçados de extinção. In Livro vermelho da fauna brasileira ameaçada de extinção 1st edn (eds A.B.M. Machado, G.M. Drummond \& A.P. Paglia), pp. 8-285. Brasília, DF: MMA; Belo Horizonte, MG: Fundação Biodiversitas.

Sato, Y., Fenerich-Verani, N., Nuñer, A.P.O., Godinho, H.P. \& Verani, J.R. (2003a). Padrões reprodutivos de peixes da bacia do São Francisco. In Águas, peixes e pescadores do São Francisco das Minas Gerais (eds H.P. Godinho \& A.L. Godinho), pp. 229-74. Belo Horizonte: PUC Minas.

Sato, Y., Fenerich-Verani, N. \& Godinho, H.P. (2003b). Reprodução induzida de peixes da bacia do São Francisco. In Águas, peixes e pescadores do São Francisco das Minas Gerais (eds H.P. Godinho \& A.L. Godinho), pp. 275-89. Belo Horizonte: PUC Minas.

Souza, G. (2004). Reprodução induzida, ontogenia inicial, etologia larval e alevinagem da piabanha (Brycon insignis, Steindachner, 1877). Dissertation, Universidade Estadual do Norte Fluminense.
Teletchea, F. \& Fontaine, P. (2010). Comparison of early lifestage strategies in temperate freshwater fish species: tradeoffs are directed towards first feeding of larvae in spring and early summer. J. Fish Biol., 77, 257-78.

Van Zutphen, L.F., Baumans, V. \& Beynen, A.C. (2001). Principles of Laboratory Animal Science: A Contribution to the Humane Use and Care of Animals and to the Quality of Experimental Results. Revised edition. Amsterdam: Elsevier.

Viveiros, A.T.M., Maria, A.N., Amaral, T.B., Orfão, L.H., Isaú, Z.A. \& Veríssimo-Silveira, R. (2012a). Spermatozoon ultrastructure and sperm cryopreservation of the Brazilian dry season spawner fish pirapitinga, Brycon nattereri. Aquacult. Res. 43, 546-55.

Viveiros, A.T.M., Isaú, Z.A, Caneppele, D. \& Leal, M.C. (2012b). Sperm cryopreservation affects postthaw motility, but not embryogenesis or larval growth in the Brazilian fish Brycon insignis (Characiformes). Theriogenology 78, 803-10.

Zaniboni-Filho, E. \& Barbosa, N.D.C. (1996). Priming hormone administration to induce spawning of Brazilian migratory fish. Rev. Bras. Biol. 56, 655-9.

Zaniboni-Filho, E., Reynalte-Tataje, D. \& Weingartner, M. (2006). Potencialidad del gênero Brycon en la piscicultura brasileña. Rev. Col. Cienc. Pec. 19, 233-40. 